\title{
ANALYSIS OF TRANSLATION TECHNIQUES IN LORE'S I AM NUMBER FOUR
}

\author{
Dede Syaifuddin Nasution \\ Universitas Negeri Medan \\ dedesyaifuddin@unimed.ac.id \\ Masitowarni Siregar \\ Universitas Negeri Medan \\ siregarmasitowarni@yahoo.com
}

Lidiman SM Sinaga

Universitas Negeri Medan

lidimansinaga@unimed.ac.id

\begin{abstract}
This final project is a study which analyzes translation techniques used in the translation of novel I am Number Four by Pittacus Lore. The translation techniques introduced by Molina and Albir (2002) is the theory I use in this study. The object of the study is to explain the techniques used by the translator in translating I am Number Four. This research is classified into descriptive research. It is the study in which I need to collect and analyze data to get conclusion. However, I also find out that it is essential to combine the qualitative approach with the quantitative one. The data are gained by reading novel, comparing the novel, identifying, classifying, counting, and conclusion. The result of the study shows that there are 12 techniques found in the data. They are, namely, adaptation, amplification, borrowing, calque, discursive creation, established equivalent, generalization, linguistic compression, literal, particularization, reduction, and transposition. The total data are 671 direct speeches of I am Number Four. The total techniques of the data found are 671. The percentage of each techniques are as follows: (1) borrowing occurs 132 times and represents 19.7\%, (2) literal occurs 119 times and represents $17.73 \%$, (3) generalization occurs 97 times and represents $14.46 \%$, (4) established equivalent occurs 94 times and represents $14.01 \%$, (5) amplification occurs 76 times and represents $11.3 \%$, (6) particularization occurs 52 times and represents $7.75 \%$, (7) linguistic compression occurs 43 times and represents $6.41 \%$, (8) reduction occurs 35 times and represents $5.22 \%$, (9) transposition occurs 12 times and represents $1.79 \%$, (10) adaptation occurs 5 times and represents $0.74 \%$, (11) calque occurs 3 data and represents $0.45 \%$, (12) discursive creation occurs 3 times and represents $0.45 \%$. Finally, the conclusions above lead me to provide the following suggestions. First, for translator: it is important to explore different translation techniques to make the translated text clear and try to give an explanation such as footnote in the novel in order to make the reader understand the text. Second, for further researcher: A further research can give knowledge that can be beneficial for the readers and can be the next related research to be reviewed. A further study is also needed to follow the development of the translation study.

Keywords: translation technique, novel, I am Number Four, descriptive qualitative
\end{abstract}




\section{INTRODUCTION}

As we know that English is International language, most of information such as books, news, magazines, journals, and articles are written in English. However, many people who understand English, like in Indonesia. People who understand English give a chance for everyone to understand anything written in English with translation. Thus, translation is very important for knowledge and communication. From the definition, translation deals with changing the form of source language (SL) into target language (TL). This concept is very basic, as explicitly stated by Larson (1984), by saying that "translation is basically change of form. In translation the form of the source language is replaced by the form of the receptor (target) language." Therefore, people who don "t understand English can receive information from the source text.

However, to be a good translator is not easy. A translator not only have to know meanings, techniques and procedures but also the culture itself. There isn" $t$ true or false in translation but the translation has to be appropriate. As said by Nida:

"a "gloss translation" mostly typifies formal equivalence where form and content are reproduced as faithfully as possible and the target language (TL) reader is able to understand as much as he can of the custom, manner of thought" of the source language (SL) context. Contrasting with this idea, dynamic equivalence tries to relate the receptor to modes of behavior relevant within the context of his own culture" without insisting that he "understands the cultural patterns of the source-language context".

According to him problems may vary in scope depending on the cultural and linguistic gap between the two or more language.

The explanation above motivates me to do this research. I will analyze the translation techniques on I am Number Four. It is novel by Pittacus Lore published in 2014. In Indonesia this novel is published by PT. Mizan, because this is an American novel, it is obvious that translator makes the reader understandable with different culture that happens in the novel. Thus, it must use techniques to make the reader love the translated novel.

\section{REVIEW OF LITERATURE}

There are some definitions from the experts about translation. Translation is the replacement of textual material in one language (source language) by equivalent textual material in another language (target language) (Catford, 1974:20).

Translation consists of changing from one state or form to another to turn into one ses own or anotheres language. In translation, the form of the surface structure of language is replaced by the form of the target language. It is done by going from the form of the first language to the form of the second language by way of semantic structure (Larson, 1984:3).

Bell (1991:13) states that if confined to a written language, translation is a cover term with three distinguishable meanings. The first meaning is the word "translating", which concerns on the process (to translate; the activity rather than the tangible object). 
The second meaning is carried by "a translation", concerns on the product of the process of translating (e.g. the translated text). The last meaning carried by translation is "translation" as the abstract concept which encompasses both the process of translating and the product of that process.

Molina and Albir (2002:509) classify translation techniques based on the following criteria:

(1) To isolate the concept of technique from other related notions (translation strategy, method and error).

(2) To include only procedures that are characteristic of the translation of texts and not those related to the comparison of languages.

(3) To maintain the notion that translation techniques are functional. Our definitions do not evaluate whether a technique is appropriate or correct, as this always depends on its situation in text and context and the translation method that has been chosen.

(4) In relation to the terminology, to maintain the most commonly used terms.

(5) To formulate new techniques to explain mechanisms that have not yet been described.

Molina and Albir (2002: 509-511) classify the translation into 18 techniques:

(1) Adaptation

It is the replacement of the cultural element of source text (ST) into the culture of target text (TT). For example: change wolf into kancil in a translation into Indonesian (Hartono, 2011:46). It happens because replacement of cultural element, wolf is a symbol of clever animal in the ST (Source Text). Thus, the translator has to find appropriate word in translating the text in order to have the same meaning from ST (Source Text).

(2) Amplification

This technique is used to introduce details that are not found in the ST (Source Text): information, explicative paraphrasing. For instance: when translating from Arabic to add the Muslim month of fasting to the noun Ramadan. Therefore, Ramadan is translated into Ramadan, the Muslim month of fasting.

(3) Borrowing

It is a type of translation which takes a word or expression straight from another language. It can be pure (without any change), e.g., to use the English word urine, horizon, diameter, stereo, and neutronin Indonesiantext, or it can be naturalized (to fit the spelling rules in the TT (Target Text), e.g., gol, informasi, and tes.

(4) Calque

It is the literal translation of a foreign word or phrase; it can be lexical or structural, e.g., the English translation Police Academy for the Indonesian Akademi Polisi.

(5) Compensation

It is to introduce a ST (Source Text) element of information or stylistic effect in another place in the TT (Target Text) because it cannot be reflected in the same place as in the ST (Source Text), for instance, the translation of English "Me?" Exclaimed Mrs. 
Albert Forrester, for the first time in her life regardless of grammar into Indonesian “Apaan?" TeriakNy. Albert Forrester, untuk pertama kali dalam hidupnya lupa pada tata bahasa (Hartono, 2011:40).

(6) Description

It means to replace a term or expression with a description of its form or/and function, e.g., to translate English cow-creamer into Indonesian poci yang berbentuk sapi untuk tempat susu.

(7) Discursive creation

It is a kind of translation which establishes a temporary equivalence that is totally unpredictable out of context, e.g., the Indonesian translation A Betrayed Son Malinkundang into Si Malinkundang.

(8) Established equivalent

It is the using of a term or expression recognized (by dictionaries or language in use) as an equivalent in the TT (Target Text), e.g., to translate the English expression Theyare as like as two peas into Mereka sangat mirip in Indonesian.

(9) Generalization

It is the using of a more general or neutral term, e.g., to translate English go by inches into sedikit demi sedikit in Indonesian. It happens because there is no expression that have the same meaning in Indonesian, so the translator translated it into more general.

(10) Linguistic amplification

It is the addition of linguistic elements. This is often used in consecutive interpreting and dubbing, e.g., to translate the English expression everything is up to you! into Indonesian as semuanya terserah anda sendiri!

(11) Linguistic compression

It means to synthesize linguistic elements in the TT (Target Text). This is often used in simultaneous interpreting and in sub-titling, e.g., to translate the English question are you sleepy? into ngantuk? In Indonesian.

(12) Literal Translation

It means to translate a word or an expression word for word, e.g., electronic mail as surat elektronik, or, upload as unggah.

(13) Modulation

It is to change the point of view, focus or cognitive category in relation to the ST (Source Text); it can be lexical or structural, e.g., to translate English you are going to have a child instead of kamu akan menjadi seorang ayah.

(14) Particularization

It is the using of a more precise or concrete term, e.g., to translate window in English as guichet (jendelatoko) in French (Hartono, 2011:52).

(15) Reduction

It is to suppress a ST (Source Text) information item in the TT (Target Text), e.g., the proposal was rejected and repudiated into usulnya ditolak when translating into Indonesian. 


\section{(16) Substitution (linguistic, paralinguistic)}

It is the change of linguistic elements for paralinguistic elements (intonation, gestures) or vice versa, e.g., to translate the Arab gesture of putting your hand on your heart as Thank you. It is used above all in interpreting.

(17) Transposition

It is the change of a grammatical category, e.g., glasses translated into Indonesian as kacamata.

\section{(18) Variation}

It is the change of linguistic or paralinguistic elements (intonation, gestures) that affect aspects of linguistic variation: changes of textual tone, style, socialdialect, geographical dialect, etc., e.g., to introduce or change dialectal indicators for characters when translating for the theater, changes in tone when adapting novels for children, etc.

\section{RESEARCH DESIGN}

This research is classified into qualitative research. It does not deal with the testing of a theory or hypothesis, but it deals with understanding of theory. In this research classification, this research is classified into descriptive research. It is the study in which I need to collect and analyze data to get conclusion.

\section{FINDINGS AND DISCUSSION}

The data are taken from the bilingual book I am Number Four by Pittacus Lore which is published by PT Mizan. The data are all the direct speeches which consist of of 671 data.

The data analysis shows that there are 12 techniques found in the data. They are: adaptation, amplification, borrowing, calque, discursive creation, established equivalent, generalization, linguistic compression, literal, particularization, reduction, and transposition. The total number of data is 671 the direct speeches of I am Number Four. The total number of techniques of the data found is 671 .

The percentage of each techniqueis as follows: (1) borrowing occurs 132 times and represents 19.7\%, (2) literal occurs 119 times and represents 17.73\%, (3) generalization occurs 99 times and represents $14.75 \%$, (4) established equivalent occurs 93 times and represents $13.86 \%$, (5) linguistic amplification occurs 76 times and represents $11.3 \%$, (6) particularization occurs 52 times and represents $7.75 \%$, (7) linguistic compression occurs 43 times and represents $6.41 \%$, (8) reduction occurs 35 times and represents 5.22\%, (9) transposition occurs 12 times and represents $1.79 \%$, (10) adaptation occurs 4 times and represents $0.59 \%$, (11) calque occurs 3 data and represents $0.45 \%,(12)$ discursive creation occurs 3 times and represents $0.45 \%$.

\section{CONCLUSIONS AND SUGGESTIONS}

\section{Conclusions}

After analyzing the data related to English-Indonesian translation techniques on I am Number Four, there are some conclusions that can be presented as follows: 
Based on the data analysis in the previous chapter, it can be concluded that there are 12 techniques found in the data. They are, namely, adaptation, amplification, borrowing, calque, discursive creation, established equivalent, generalization, linguistic compression, literal, particularization, reduction, and transposition. The total data are 671 direct speeches of I am Number Four. The total techniques of the data found are 671. The percentage of each techniques as follows: (1) borrowing occurs 132 times and represents 19.7\%, (2) literal occurs 119 times and represents 17.73\%, (3) generalization occurs 99 times and represents $14.75 \%$, (4) established equivalent occurs 93 times and represents $13.86 \%$, (5) linguistic amplification occurs 76 times and represents 11.3\%, (6) particularization occurs 52 times and represents $7.75 \%$, (7) linguistic compression occurs 43 times and represents $6.41 \%$, (8) reduction occurs 35 times and represents 5.22\%, (9) transposition occurs 12 times and represents $1.79 \%$, (10) adaptation occurs 4 times and represents $0.59 \%$, (11) calque occurs 3 data and represents $0.45 \%$, (12) discursive creation occurs 3 times and represents $0.45 \%$.

\section{Suggestions}

The conclusions above lead me to provide the following suggestions:

1) For the translator

It is important to explore different translation techniques to make the translated text clear and try to give an explanation such as footnote in the novel in order to make the reader understand the text.

2) For further researcher

A further research can give knowledge that can be beneficial for the readers and can be the next related research to be reviewed. A further study is also needed to follow the development of the translation study.

\section{REFERENCES}

Bell, Roger.T. 1991. Translation and Translating. London: Longman Group UK Limited.

Catford, J.C. 1974. A Linguistic Theory of Translation. London: Oxford University Press.

Larson, Mildred L. 1984. Meaning-Based Translation: A Guide to Cross Language Equivalent. London: University Press of America .

Lore. Pittacus. 2014. I am Number Four Translated by Nur Aini. Bandung: Mizan Media Utama.

Lore. Pittacus. 2014. I am Number Four. America: Harper Collins Publisher.

Molina and Albir. 2002. "Translation Technique Revisited: A Dynamic and Functional Approach”. Meta, XLVII, 4. Spain, Barcelona: Universitat Autònoma de Barcelona. 